\title{
Rethinking the Public-Private Law Divide in the Age of Governmentality and Network Governance
}

\section{A Comparative Analysis of French, English and Dutch Law}

\author{
Lukas van den Berge \\ Erasmus School of Law Rotterdam, Erasmus University Rotterdam, \\ the Netherlands \\ l.vandenberge@law.eur.nl
}

\begin{abstract}
This article presents an analysis of the ways in which the public-private law divide is envisioned in French, English and Dutch law. First, it explains why French law's tradition of regarding public and private law as 'two separated worlds' is now outmoded, failing to live up to the present trends of 'governmentality' and 'network governance' determining the modern art of government. Subsequently, it argues that the holistic idea of English 'common law' as French law's conceptual counterpart is equally outmoded, with its ideology of 'self-government' within a 'stateless society' being out of touch with an age of managerialism and 'governmentality' in which the state withdraws from society only to increase its grip on societal processes. Finally, it proposes a paradigm recently developed in Dutch doctrinal thought as an attractive theoretical framework for structural innovations that may contribute to a stable and legitimate system of modern European public law that attunes to its present context without being alienated from its central classical tenets - be it either those rooted in the French or the English tradition.
\end{abstract}

\section{Keywords}

public-private divide - public law - legal theory - comparative administrative law governance - neoliberalism

(C) VAN DEN BERGE, 2018 | DOI 10.1163/22134514-00502002

This is an open access article distributed under the terms of the prevailing CC-BY-NC license at the time of publication. 
What is public law? What establishes its element of publicness, distinguishing it from private law? Such deceivingly simple questions are of central importance to current legal problems but receive little attention in legal scholarship. Invented in response to feudalism as a system in which public and private powers remain undifferentiated, the idea of public law gained particular momentum in the nineteenth century as a decisive era of modern law's development. Within the realm of public law, the state was envisioned to hold sway over its subjects by an unbound public imperium, never employed at will but strictly guided by rules and principles that serve the general interest. With public law thus setting up relations of strict verticality, private law would be characterized by legal horizontality, governing civil society as a space of free encounters between individuals seeking to advance their private interests. ${ }^{1}$

With the rise of the social state making an end to the liberal era of laissezfaire', the concept of a well-defined public-private divide met with increasing criticism. Some even pronounced its 'death', fallen prey to a severe 'osmosis' that would have made the idea of a clear-cut divide untenable. ${ }^{2}$ The idea of the general interest as public law's abstract point of orientation would only obscure the fact that any government action (or inaction) inevitably advances the interests of the one above the other. The concept of civil society as a horizontal space of exchange would be equally misleading, denying unequal power relations that make real horizontality impossible. ${ }^{3}$ Notwithstanding these criticisms, however, the public-private dichotomy remained of central importance for the ways in which we tend to conceptualize and organize the legal landscape, ranging from academic departments and curricula to the distribution

1 Cf, for example, R.C. van Caenegem, A Historical Introduction to Western Constitutional Law (Cambridge: Cambridge University Press, 1995); M. van Creveld, The Rise and Decline of the State (Cambridge: Cambridge University Press, 1999).

2 For the pronouncement of the death of the public-private divide (and the emphatic defence of its lasting importance), see, most notably, E. Forsthoff, Der Staat der Industriegesellschaft dargestellt am Beispiel der Bundesrepublik Deutschland (München: Beck, 1971) p. 21.

3 See, e.g., D. Kennedy, "The Structure of Blackwell's Commentaries", Buffalo Law Review 28 (1979) 205-382, dismissing the public-private distinction at p. 217 as a 'false dichotomy', traceable to a 'mechanism of denial', a 'splitting of the universe' into 'two opposed imaginary entities'. For similar CLS critiques of the public-private distinction, see esp. J.M. Amaya-Castro, Human Rights and the Critiques of the Public-Private Distinction (Amsterdam: Free University Amsterdam, 2010) pp. 52-122. 
of judicial competences and default principles of substantive and procedural law. ${ }^{4}$

In the current neoliberal era, centrifugal forces of globalization, privatization and marketization have further problematized the idea of public law as a separate legal regime by making the distinction between the public and the private even fuzzier. The present time has seen a fragmentation of the public sphere, a breakup of public imperium into separate pieces, not only entrusted to supra- or subnational authorities but also left in the hands of private actors. ${ }^{5}$ Exposed to the rigours of a globalized economy, modern states have had little choice but to follow depoliticized economic policies of privatization, reduced public spending and marketization of the government itself. ${ }^{6}$ Replacing centralized bureaucratic rule, new legitimacy was sought in a shift from centralized government to network governance as an allegedly more effective method of regulation and policy-making. ${ }^{7}$

For one thing, the neoliberal model entails the restructuring of administrative agencies, decentring public power and mimicking the market by putting public actors under a competitive regime of benchmarks and policy targets. Neoliberalism as it is classically understood by Foucault and others typically entails 'governmentality' as a strategy of 'conduct of conduct', with the government withdrawing from society only to increase its grip on societal processes. ${ }^{8}$ Setting up a wide range of 'partnership agreements' with private

4 Cf., e.g., A. von Bogdandy, "The Idea of European Public Law Today", in: A. von Bogdandy, P.M. Huber and S. Cassese (eds.), The Max Planck Handbooks in European Public Law. Vol. !: The Administrative State (Oxford: Oxford University Press, 2017) pp. 1-29.

5 C. Crouch, K. Eder and D. Tambini (eds.), Citizenship, markets, and the state (Oxford: Oxford University Press, 2001).

6 C. Crouch, Post-Democracy (Cambridge: Polity Press, 2004).

7 For a critique on network governance, see e.g. J.S. Davies, Challenging Governance Theory (Bristol: Policy Press, 2011); M. Raco, State-led Privatisation and the Demise of the Democratic State (London: Ashgate, 2013). More positive accounts are provided by J. Braithwaite, Regulatory Capitalism (Cheltenham: Edward Elgar, 2008); D. Levi-Faur, "The Welfare State: A Regulatory Perspective", Public Administration 92 (3) (2014) 599-614.

8 M. Foucault, The Birth of Biopolitics. Lectures at the Collège de France 1978-1979 (Michel Senellart ed., Graham Burchell tr., London: Palgrave Macmillan, 2008), with the lecture of 7 February 1979 explaining about the German 'Freiburg School' of neoliberalism and the lecture of 14 March 1979 analysing the American neoliberalism of the Chicago School. A leading text applying Foucault's insights to modern society is N. Rose, Governing the Soul: The Shaping of the Private Self ( $2^{\text {nd }}$ edition, London/New York: Free Association Books, 1999), laying out neoliberalism's 'technologies of autonomy' at pp. 244-258. 
actors, the neoliberal model tends to blur the distinction between the public and the private almost beyond recognition, infusing both domains with a spirit of managerialism and 'governmentality' that tends to measure everything by quantitative standards of output and effectiveness. ${ }^{9}$ Against the backdrop of the current era of neoliberalism and network governance, many prominent scholars have carried the idea of public law as a legal realm distinct from private law to the grave, arguing that the structural transformation of the public sphere does not allow for such binary thinking. ${ }^{10}$

Does public law still have a future, or should we arrange for its proper burial? What could its element of 'publicness' still entail in an era of globalization, privatization and marketization of the public sphere? With the ongoing obfuscation of the public-private distinction, the basic grammar of public law as we inherited it from earlier generations is in need of serious rethinking. Public law's traditional insistence on legal verticality and the undivided general interest as its major points of reference seems more and more out of touch with the 'horizontalized' and 'fragmented' socio-cultural and economic reality that it is supposed to regulate. Unlike Baron Münchhausen, public law seems unable to pull itself out of the swamp by its own wig. Pragmatic adjustments to its established dogmatic layout alone do not suffice."

In order to find possible ways for public law to be effectively renewed, something else is needed: a thorough re-investigation of its deep-rooted precepts and theoretical conjectures themselves. ${ }^{12}$ Only in that way could one hope to pave the way for a model of public law that remains true to principled values of the rule of law and the common good, but is flexible enough to cope with societal changes that one could applaud or deplore, but seem inevitable anyway. Which could be the fundaments for a system of public law that really meets

W Brown, Undoing the Demos. Neoliberalism's Stealth Revolution (New York: Zone Books, 2015) $115^{-150 .}$

10 See, e.g., the majority of the essays collected in C. Mac Amhlaigh, C. Michelon and N. Walker (eds.), After Public Law (Oxford: Oxford University Press, 2013), with the editors stating in the introduction that the idea of public law now 'passes away or mutates into something significantly different' (p. 2).

11 Cf., e.g., L. van den Berge, “The Relational Turn in Dutch Administrative Law”, Utrecht Law Review 13(1), (2017) 99-111, with further references.

12 Cf., e.g., A. von Bogdandy, "Verwaltungsrecht im europäischen Rechtsraum”, in: A. von Bogdandy, S. Cassese and P.M. Huber (eds.), Handbuch Ius Publicum Europaeum, vol. 4 (Heidelberg: Müller, 2011) 4-7; M. Ruffert, "The Transformation of Administrative Law as a Transnational Methodological Project”, in: M. Ruffert (ed.), The Transformation of Administrative Law in Europe (München: Sellier, 2006) pp. 3-52. 
the challenges of the current neoliberal era? Could we in some way remain faithful to the idea of public law as a distinct legal regime, or should we abandon that conception altogether?

In this article, I will set out to find some tentative answers to such questions from the combined perspectives of intellectual history, legal theory and comparative law. First, I will provide a short account of the French law's tradition seminal for the development of public law throughout the continent - of regarding public and private law as 'two separated worlds', each dispensing of rules and procedures of its own. Though shaken by the rise of the welfare state, the classical idea of public and private law as two distinct bodies of law basically stands straight up to the present day. With the blurring of public and private in the neoliberal era, however, the public-private divide has been severely challenged in recent years, being confronted with a social reality that is more at odds with the French ideology of public and private law as distinct realms than ever before.

Then, I will move to the holistic idea of English 'common law' as French law's ideological counterpart. Traced back to the invented tradition of a 'stateless society', English law traditionally denounces the public-private divide as fundamentally strange to English law, at odds as it would be with its proud ideology of decentralization and self-government. With modern times seeing the state taking a firm grip on society, however, classical English holism has become untenable, giving way to the emergence of public law as a legal domain of its own, gradually - but often still somewhat grudgingly - recognized in doctrinal thought.

Subsequently, I will discuss the idea - originally of German descent, but particularly ingrained in the Dutch legal tradition - of regarding public law as a domain of artificial exception, now generally regarded as obsolete but still resounding in Dutch administrative law's rather formalist identity. The guise of public law as a man-made sphere of legal exclusion from private law has loaded it with a vertical and rather abstract legal grammar that seems out of touch with the horizontalized and privatized social reality that it is now supposed to regulate.

What, then, could be a viable way forward for public law, burdened with the ideological weight of various traditions that seem out of touch with its modern neoliberal context? With the French, English and Dutch traditions each now being arguably obsolete, I will present a paradigm shift recently adopted in Dutch doctrinal thought as an attractive theoretical framework for structural innovations that may contribute to a stable and legitimate system of European public law that attunes to its modern socio-cultural and institutional context. 
In France, public and private law are traditionally conceived as 'two separated worlds', unable to live entirely in peace, but 'neither enough friend nor foe' to get thoroughly acquainted. ${ }^{13}$ For one thing, French administrative law is based on the idea that the government - representing the nation - has special rights and duties of which the extent can only be determined by rules and principles that differ from those that fix the legal relations of citizens amongst each other. Reminiscent of the designs of theoreticians like Bodin and Hobbes, it envisions the government above civil law, with its absolute position necessary to prevent a fall-back to a state of nature that makes life nasty, brutish and short or otherwise unbearable. ${ }^{14}$

Secondly, French public law rests on the - mistaken - interpretation of Montesquieu's trias politica doctrine as a strict separation of powers, rigidly preventing the legislature, the government and the courts from encroaching upon one another's domain. ${ }^{15}$ That feature is well expressed in article 13 of the Law of 16-24 August 1790 on the organisation of the judiciary. That article states that ' $[\mathrm{i}] \mathrm{t}$ shall be a criminal offense for the judges of the ordinary court to interfere in any manner whatsoever with the operation of the administration' and forbids those judges 'to call administrators to account before them in respect of the exercise of their official functions.'. ${ }^{16}$

In accordance with public law's distinct status, protection against government actions in administrative matters was initially only possible within a

13 A. de Tocqueville, Correspondance anglaise, Oeuvres Complètes 6 (Paris: Gallimard, 1991) p. 66: 'Vous savez que, chez nous, le droit administratif et le droit civil forment comme deux mondes separés, qui ne vivent point toujours en paix, mais qui ne sont ni assez amis ni assez ennemis pour se bien connaître.' See also A.V. Dicey, Introductory to the Study of the Law of the Constitution, ed. J. Allison (Oxford: Oxford University Press, 2013 [1885]) p. 236.

14 Dicey (supra note 13) pp. 237-238; J Allison, A Continental Distinction in the Common Law. A Historical and Comparative Perspective on English Public Law (Oxford: Oxford University Press, 1994) pp. 44-46.

15 P. Gonod, "Grundzüge des Verwaltungsrechts in gemeineuropäischer Perspektive: Frankreich", in: A. von Bogdandy, S. Cassese and P.M. Huber (eds), Handbuch Ius Publicum Europaeum (Heidelberg: Müller, 2014) pp. 163-164; L. Neville Brown and J.S. Bell, French Administrative Law (Oxford: Oxford University Press, 1998) pp. 9-14. On the reception history of Montesquieu's separation of powers doctrine in continental administrative law scholarship, see esp. L. van den Berge, "Montesquieu and Judicial Review of Proportionality in Administrative Law: Rethinking the Separation of Powers in the Neoliberal Era", EJLS 10 (1) (2017) 204-233.

16 The translation is adapted from Brown and Bell (supra note 15) p. 46. 
system of 'justice retenue', entailing review of government actions within the hierarchy of government itself, only gradually replaced by a system of 'justice déléguée' that outsources judicial protection to administrative courts of de facto independence. ${ }^{17}$ Even in times of industrialization and growing involvement of the state with the 'system of needs' of society, the vision of administrative and private law as 'two separated worlds' remained unshaken.

The idea of two legal columns, each governed by their own rules and principles and falling under the jurisdiction of their own courts, clearly emerges from the Tribunal of Conflict's epoch-making ruling in Blanco, generally regarded as the starting point of a series of grands arrêts that have shaped modern French administrative law. ${ }^{18}$ When five-year-old Agnès Blanco had been severely injured by a cart belonging to a state owned tobacco factory in Bordeaux, her father brought a suit to the ordinary court, claiming damages under articles 1382, 1383 and 1384 of the French Civil Code. The competence of the ordinary court was denied by the Tribunal des Conflits, considering that the rules from civil law only pertain to the relations of private legal subjects towards each other.

In the Tribunal's reasoning, liability for damages caused by those performing a 'service public' - like the workers of the tobacco factory who caused the accident - is regulated by 'règles speciales', varying with the 'requirements of the public service' and the 'necessity to reconcile the rights of the state with rights of private persons'. Thus, the court neglected the fact that there was little that substantively discerned the factory workers and their state owned factory from other such workers at private enterprises. While driving their tobacco carts, they were considered to perform a public service that exempted them from the rules of civil law. With the general interest at stake, the state as the workers' employer could only be held liable by an administrative court, steeped in public law as a separate body of rules and principles. ${ }^{19}$

With the ongoing 'osmosis' between state and society that is typical of the developing social state, the idea of public and private law as two distinct legal spheres became under increasing pressure. On the one hand, the state extended its engagement with commercial and industrial activities, further expanding its grip on economic life. On the other hand, the welfare state saw the rise of large corporations and other private actors taking up tasks of public management that were previously in the hands of the state. The liberal concept

17 Brown and Bell (supra note 15) pp. 47-48; Gonod (supra note 15) pp. 166-168.

18 Blanco, TC 8 February 1873 . For a recent discussion of Blanco's enduring importance on the central tenets of French administrative law, see M. Long and others, Les grands arrêts de la jurisprudence administrative (Paris: Dalloz, 2015) pp. 1-8. 
of an impermeable watershed between the public and the private - a clear borderline ensuring that 'never the twain shall meet' - thus became untenable, giving way to the acknowledgment that the dividing line is in fact quite porous and often difficult to draw.

For one thing, such developments instigated the introduction of the 'service public à caractère industriel et commercial', adopting the view that commercial and industrial actions of government fall under the competence of the ordinary court. In Bac d'Eloka, the Tribunal des Conflits considered that the operation by the state of a ferryboat crossing a sea lagoon in Ivory Coast should not be regarded as a 'public work' (ouvrage public), contemplating that the colonial authorities exploited the service 'to the same conditions as an ordinary entrepreneur' (dans les mêmes conditions qu'un industriel ordinaire). ${ }^{20}$ And why should such a business be controlled by rules and procedures that essentially differ from those that regulate other commercial enterprises?

Vice versa, it was acknowledged that public services controlled by the 'special rules' of public law can also be performed by private actors. In the ground-breaking case of Caisse primaire 'Aide et Protection', the Conseil d'État considered that written and unwritten rules of public law pertain to any agent that executes a public service, 'even if that agent has the character of a private enterprise' (même si cet organisme a le caractère d'un établissement privé). ${ }^{21}$ With such recalibration of the public-private divide, the French legal system responded to the coalescence of state and society without giving up the idea of public and private law as two distinct bodies of law, perhaps more intertwined than before, but each nevertheless still guided by its own set of values and principles. $^{22}$

With the shift from government to governance, the traditional French idea of public and private law as two separated worlds was further challenged by privatization and the breakup of the general interest and public imperium that is typical of the neoliberal era. With the public sphere fragmented into pieces, infused with a governmental rationality of orchestrated competition, the borderline between the public and the private sphere - already vague and permeable - was blurred and punctured even further. This is well illustrated by the case of $S C E A$ du Cheneau, in which the Tribunal des Conflits overturned

$20 \quad$ Bac d'Eloka (also known as Société commerciale de l'ouest Africain), TC 22 January 1921.

21 Caisse primaire 'Aide et protection', CE 13 May 1938.

22 See the recent (as yet unpublished) dissertation of J. Goossens, The Future of Administrative Justice. Judicial Review of Administrative Action in Comparative Perspective (Ghent 2016) pp. 187-203 for a handsome overview of this development. 
earlier case law that awards the competence to review the legality of administrative decisions exclusively to the administrative court. ${ }^{23}$

Before the civil court, SCEA du Cheneau - a producer of pork meat demanded reimbursement of subscription fees paid to Inaporc, a private organisation regulating the market. It argued that a regulatory act of the government requiring producers of pork meat to be member of Inaporc entails an infringement of European standards of competition law, dismissing the regulatory act as a forbidden measure of state aid. Pointing at the line of reasoning established in cases like Septfonds, the government asserted that the civil court is only competent to interpret regulatory administrative acts; as far as it concerns their validity, it would be obliged to suspend judicial proceedings and pose a preliminary question to the administrative court. ${ }^{24}$

In partial confirmation of Septfonds, the Tribunal affirms in SCEA du Cheneau that the French interpretation of the separation of powers doctrine - as it is laid down in article 13 of the Law of $16-24$ August 1790 - entails that only the administrative court is competent to review the legality of administrative decisions. Contrary to Septfonds, however, the Tribunal considers that principles of due administration of justice demand the civil court to review the validity of administrative acts on its own accord if it can do so on the basis of settled administrative case law. Moreover, the European principle of effectiveness would require the civil court to review the lawfulness of administrative decisions in view of EU law; if necessary, preliminary questions should be posed directly to the CJEU rather than taking the unnecessary byroad of the national administrative court. ${ }^{25}$

The ongoing neoliberal intertwinement of the public and private sphere leaves hardly any clear substantive differences between social relations governed by public law on the one hand and those regulated by private law on the other hand. French jurisprudence responds by further dogmatic osmosis between public and private law of which SCEA du Cheneau is only one example. Whereas this last case destabilizes the idea of a clear distinction by extending the competence of the civil court, a case like APREI does the opposite and extends the competence of the administrative court. ${ }^{26}$ Treading further on the path that was taken with Caisse primaire 'Aide et Protection', the Conseil d'État further broadened its doctrine of the 'service public', with that notion now also comprising acts of private bodies that serve the general interest without any

\footnotetext{
23 SCEA du Cheneau, TC 17 October 2011. See also Long and others (supra note 18) 882-890.

24 Septfonds, TC 16 June 1923; see also Brown and Bell (supra note 15) p. 179.

25 Cf., e.g., Goossens (supra note 22) p. 191.

26 APREI, CE 22 February 2007.
} 
explicit government tutelage or any clear recourse to prerogatives of public power. ${ }^{27}$ Instead, it is regarded as decisive whether or not the government seems to have consciously entrusted the private actor with its public mission. ${ }^{28}$

In the light of such decisions, some commentators have argued that the traditional idea of public and private law as 'two separated worlds' - corresponding with a 'jurisdictional dualism' (dualisme juridictionnel) between the civil and administrative courts - is now obsolete. Among its most prominent opponents are Roland Drago and Marie-Anne Frison-Roche, who dismiss the publicprivate divide not so much for its practical disadvantages. Above all, they defy the traditional idea of the state as a 'grand honnête homme' that essentially differs from other legal persons and therefore deserves special judicial treatment as an actor that hovers above the law rather than being fully submitted to it. ${ }^{29}$

As Drago and Frison-Roche argue, the days of the traditional French conception of the state as some elevated politico-theological entity, a mysterious divinity still available to a deserted and disenchanted world, are finally numbered. Instead, they claim that it is time for a 'banalization' of public law, drawing on modern insights from sociology and philosophy that label the state as an organisation that may be important and powerful, but nevertheless should be regarded as an organisation like any other. Bereft of its metaphysical nature, the state should now be understood as 'an organisation necessary for the fulfilment of certain social functions', like any other organisation intent on preserving and developing itself. ${ }^{30}$ With the state having fallen off its pedestal, Drago and Frison-Roche reject the French tradition of dual jurisdiction and dual legal systems. They regard the 'summa divisio' of public and private law as a fallacious opposition, an ill-chosen distinction that severely damages the 'factual unity' (unité réelle) of the social world that law is supposed to regulate, distracting from a much more heterogeneous range of social differences and power relations that would instead require law's primary attention. ${ }^{31}$

It should be noted, however, that such views do not express the French mainstream opinion. Deeply ingrained in French judicial culture, the notion of public and private law as two different legal domains has proven to be more

27 See, e.g., Brown \& Bell (supra note 15) 129-134.

28 Cf., e.g., C. Boiteau, "Vers une définition du service public? À propos de l'arrêt du Conseil d'Etat, Section, 22 février 2007, Association du personnel relevant des établissements pour inadaptés) (APREI)", Revue française de droit administratif 23 (2007) 803.

29 R. Drago and M. Frison-Roche, "Mystères et mirages des dualités des ordres de juridictions et de la justice administrative" Archives de philosophie du droit 41 (1997) 135.

30 Drago and Frison-Roche (supra note 29) 141, referring to the state as 'une organisation nécessaire pour remplir certaines fonctions sociales'.

$31 \quad$ Ibid. 142-143. 
pervasive than social reality seems to justify. In fact, a majority of scholars subscribe to the dual system as one of France's many great establishments, a valuable asset that should be cherished also in the neoliberal era of globalisation and privatisation. ${ }^{32}$ Undeniably, however, the two distinct domains of public and private law are like the twin stars of Gemini, which 'we still admire in the sky, but whose exalting lights may have already disappeared', farther removed from us than we tend to imagine. ${ }^{33}$

\section{Common Law}

The traditional French idea that the government is above the law, having special rights and obligations in order to liberate its subjects of private interdependencies, has its counterpart in the English adherence to a 'supremacy of law' that binds the government no less than ordinary citizens. ${ }^{34}$ 'With us', as Dicey proudly proclaims, 'every official, from the Prime Minister down to a constable or a collector of taxes, is under the same responsibility for every act done without legal justification as any other citizen' ${ }^{35}$ Evidently, the English concept of the 'rule of law, not man' does not preclude that officials are subject to laws 'which do not affect the rest of the nation', being governed, to a certain extent, by 'what may be termed official law'. ${ }^{36}$ In no way, however, would this be inconsistent with the principle that all legal subjects are likewise subjected to 'the law of the land'.

32 Cf., e.g., B. Stirn, "Quelques réflexions sur le dualisme juridictionnel", Revue générale de droit processuel 3 (1996) 41-51; J.B. Auby, "Le rôle de la distinction du droit public et du droit privé dans le droit français", in: J.B. Auby and M. Freedland (eds), The Public Law/ Private Law Divide. Une entente assez cordiale? (Oxford: Hart Publishing, 2006) pp. 11-19; D. Truchet, "Plaidoyer pour une cause perdue: la fin du dualisme juridictionnel", in: A. Van Lang (ed), Le dualisme juridictionnel: limites et mérites (Paris: Dalloz, 2007) p. 201.

33 As famously stated already by M. Hauriou, "Conseil d'État 29 novembre 1912: recevabilité de la tierce-opposition contre arrêt prononçant annulation pour excès de pouvoir", Revue du droit public et de la science politique en France et à l'étranger 1 (1914) 376: 'Nous l'admirons encore de confiance, mais il est comme cette étoile temporaire des Gémeaux, que nous voyons dans le ciel, et dont l'exaltation lumineuse a peut-être disparu depuis déjà des centaines d'années, tellement elle est loin de nous. Nous l'admirons encore, et il n'est déjà plus ou, du moins, il n'est plus qu'une pièce de musée, un objet d'art délicat, une merveille de l'archéologie juridique.'

34 See esp. Dicey (supra note 13), comparing the English 'rule of law' to French administrative law in Chapter 12, pp. 368-413 (seventh edition).

35 Dicey (supra note 13) p. 100.

$36 \quad$ Ibid. pp. 100-101. 
In opposition to the continental legal tradition, the English legal tradition as it has been epitomized by Dicey, at least - does not consider the special rules pertaining only to government officials as essentially different from other special rules like those directed at landlords, bankers or employers. Instead of understanding public and private law as two separated worlds, it adheres to the concept of a 'common law' binding citizens and government alike in the same legal realm. ${ }^{37}$ Continental public law typically follows contractarians like Hobbes, Rousseau and Kant in the belief that the conversion of a natural to a civil state may only succeed when the transformation is a total one, leaving no room for any subjective rights of citizens towards the government as a remainder of the state of nature. English law, however, rather sticks to the Lockean idea of 'inalienable' subjective rights of individual citizens towards the government, with the latter being bound in its relation to its subjects by unwritten legal principles that do not essentially differ from those that bind ordinary citizens amongst each other. ${ }^{38}$

Resisting a political theory that is conducive to administrative centralization, English law finally resolved conflicts between Crown and Parliament decidedly in favour of the latter, indulging in a long-standing English tradition of legislative and judicial supremacy instead of centralized rule by a government exempt from law, with the Crown belonging to the body politic rather than the other way round. ${ }^{39} \mathrm{An}$ invented tradition, perhaps, but nevertheless a 'peculiarity of our polity' that is cherished by Dicey as a great accomplishment, a source of 'admiration or astonishment' for great foreign minds like those of Voltaire, De Tocqueville and Gneist. ${ }^{40}$ In neglect of the unique position of the government as the sole wielder of public force, capable of unilaterally determining the legal position of its subjects, the Victorian England of Dicey has been described by some as a 'stateless society' lacking a legal framework that recognizes the commonwealth as something different from a private enterprise. ${ }^{41}$

In the era of laissez-faire, the lack of such a framework could remain more or less unnoticed, with civil society heavily relying on the ideology of

37 Cf., e.g., P. Craig, Public Law and Democracy (Oxford: Oxford University Press, 1990) pp. $27-29$.

38 G. Gozzi, "Rechtsstaat and individual rights in German history", in: P. Costa and D. Zolo (eds), The rule of law. History, theory and criticism (Berlin: Springer, 2007) p. 237; M. Loughlin, Foundations of Public Law (Oxford: Oxford University Press, 2010) pp. 312-324.

39 Allison (supra note 14) pp. 72-81.

40 Dicey (supra note 13) p. 95.

41 K. Dyson, The State Tradition in Western Europe (Oxford: Oxford University Press, 1980) p. $5^{2}$. 
'self-government' to solve its most urgent problems. Confronted with the many challenges of industrial and post-industrial society, however, the 'myth' - as some have called it - of a stateless system could no longer be sustained. ${ }^{42}$ As Cane describes, the first six decades of the twentieth century saw the consolidation and strengthening of centripetal forces to the point where the English system was designated by critics as an 'elective dictatorship', with the government steering society while actively protecting the health, security and well-being of its citizens. ${ }^{43}$ With the government making ample use of its prerogatives, the ancient ideological denial of the administration's fundamental particularity lost its rhetorical force. Elevating itself above its subjects in order to solve society's many problems, the government could no longer persuasively present itself as a legal actor on equal footing with its subjects, equally bound by the supremacy of common law like anyone else. Instead, the dogmatic recognition of its special legal position seemed inescapable. ${ }^{44}$

Faithful to the Dicean ideology of commonality and statelessness, however, it took English law a long time to recognize this. Lacking a theory of public law, protection against the growing English state apparatus was initially primarily provided by a plethora of tribunals and committees serving as judicial bodies but ultimately falling within the hierarchy of the government itself. Gradually, however, the common-law courts developed an arsenal of writs and remedies that could serve as more or less effective instruments against government actions, with reforms in the late seventies setting up an administrative chamber at the Queen's Bench Division of the High Court commonly known as 'administrative court'. Notwithstanding these developments, it could reasonably be argued until the early eighties that 'the public-private distinction [...] is wholly incompatible with the English tradition', unlikely ever to obtain an enduring place within the English common law jurisprudence. ${ }^{45}$

After the ground-breaking case of O'Reilly versus Mackman, however, such faithful persistence with the Dicean tradition has become untenable. In that case, Lord Diplock famously stated that it would be 'an abuse of the process of the court' to permit a person seeking judicial protection against the

42 See M. Loughlin, "Staat, Verwaltung und Verwaltungsrecht", in: A. von Bogdandy, S. Cassese and P.M. Huber (eds.), Handbuch Ius Publicum Europaeum (Heidelberg: Müller, 2010) p. 119, referring to the rootedness of the 'supremacy of law' in an Anglo-Saxon tradition of self-government and decentralised rule as 'der Mythos von der alten Verfassung'.

43 P. Cane, Controlling Administrative Power. An Historical Comparison (Cambridge: Cambridge University Press, 2015) p. 42.

44 Loughlin (supra note 42) pp. 141-144.

45 C. Harlow, "Public' and 'Private' Law: Definition without Distinction", Modern Law Review $43(3)(1980) 242$. 
infringement of rights by a public authority 'to which he was entitled to protection under public law to proceed by way of an ordinary action. ${ }^{46}$ Establishing the exclusivity of judicial review by the administrative court, O'Reilly versus Mackman sealed the procedural 'divorce of public and private law' that was precipitated by a gradual emergence of public law as a response to the growing engagement of the government with society. ${ }^{47}$ Thus the case promoted the development of a theory of public law that would ultimately also prove to be of substantive importance. ${ }^{48}$ De Smith's Judicial Review now even presents English administrative law as 'one of the most celebrated products of our common law', dismissing Dicey's ideological resistance against that branch of law as a ghost from the past. ${ }^{49}$

Public and private law's divorce as it was confirmed in O'Reilly $v$ Mackman met with fierce criticism. Critics were particularly concerned about the 'waste of time and money on litigation merely about procedure', considering the case as an unfortunate move away from the legal merits of the decisions of public authorities, emphasizing preliminary questions and technicalities instead. ${ }^{50}$ O'Reilly v Mackman necessitated intricate surgical operations for the courts to sever public from private law; never having done so previously, these operations confronted them with quite some difficulties. ${ }^{51}$ With the remedy of judicial review only being available where 'an issue of public law is involved', the question was raised how such issues could be properly identified. ${ }^{52}$ It soon turned out that a clear dividing line between public and private law is often impossible to draw. No wonder, therefore, that the Court of Appeal adopted a more flexible approach in Clarkv University of Lincolnshire \& Humberside, ${ }^{53}$ partly implementing and partly anticipating changes to the Civil Procedure

46 O'Reilly v. Mackman [1982] 3 WLR 1096.

47 W. Wade and Ch. Forsyth, Administrative Law (Oxford: Oxford University Press, 2014) pp. 568-573.

48 D. Oliver, Common Values and the Public-Private Divide (Cambridge: Cambridge University Press, 1999) p. 8off, explaining how the divorce of public and private procedures instigated the further development of rules and principles that are particularly tailored to the exertion of public prerogatives.

49 C.M. Donnelly, De Smith's Judicial Review (London: Sweet \& Maxwell, 2007) p. 8.

$50 \quad$ W. Wade, "Procedure and Prerogative in Public Law", Law Quarterly Review 101 (1985) 180; among much more, see also J.A.Jolowicz, "The Forms of Action Disinterred", Common Law Journal 42(1) (1983) 15-18.

$51 \quad$ Wade and Forsyth (supra note 47) p. 572.

$5^{2} \quad$ R. v. East Berkshire Health Authority, ex parte Walsh [1985] Qв 152.

53 Clark v. University of Lincolnshire \& Humberside, [2000] 1 WLR 1988. 
Rules that were meant to abate the negative effects of the 'wholly undesirable wrangles' of the rigid system of procedural exclusivity to which O'Reilly $v$ Mackman had given rise.$^{54}$ With public and private law still being 'divorced', however, the distinction between 'matters of public law' and other matters continues to confront the legal community with many difficult if not unsolvable problems. ${ }^{55}$

The full unfolding of Thatcherism that followed O'Reilly $v$ Mackman made the legal disconnection of public from private law even harder. In the wake of the all-out shift from government to decentralized and privatized governance, a formalist approach - focusing merely on the formal sources of a particular authority's legal powers - soon proved to dissatisfy. ${ }^{56}$ Therefore, the courts were eager to embrace a functional approach that was better tailored to the social reality of new public management. In the landmark case of Datafin, for instance, the administrative court considered that a decision of the Panel on Take-overs and Mergers - an organisation without any statutory or prerogative powers but nevertheless regulating an important part of the financial market is susceptible for judicial review. Lacking any public authority de jure, the Panel exercised immense power de facto, performing an important public duty with the government relying upon it as 'an implied devolution of power'. Recognizing the 'realities of executive power' in the neoliberal era, the court deliberated that '[t]he City is not a club which one can join or not at will', dismissing the idea of the Panel as a mere self-regulatory organisation whose authority is given with the free consent of its subjects. ${ }^{57}$

The limits of the new substantive approach to the distinction between matters of public and private law are by no means certain. In their determination not to allow any powerful quasi-governmental body to opt out of the legal system, the court inspired litigants to find a 'public element' in many actions of non-statutory bodies traditionally considered as private organisations. Without any statutory basis, for instance, the Jockey Club operates a factual monopoly in the regulation of British horse racing; as such, it is a powerful body whose authority can only be ignored at the price of exclusion from that sport. In a controversial case, a racehorse owned by Aga Khan was disqualified and its trainer fined by the disciplinary committee of the Jockey Club. Although the Court of Appeal acknowledged that 'the Jockey Club exercised dominant

\footnotetext{
54 Wade and Forsyth (supra note 47) pp. 581-583.

55 Wade and Forsyth (supra note 47) p. 532ff. with further references.

56 Cf., e.g., P. Cane, Administrative Law (Oxford: Oxford University Press, 2004) pp. 3-4.

57 R. v. Panel on Take-overs and Mergers, ex parte Datafin Plc [1987] Qв 815 (Qв) 847 .
} 
control over racing activities in Great Britain its powers and duties were in no sense governmental but derived from the contractual relationship between the club and those agreeing to be bound by the Rules of Racing. Therefore, the court decided that the club's decision was not amenable for judicial review. ${ }^{58}$ That decision was later confirmed in cases like $R$ (Mullins) $v$ the Jockey Club, be it that the court now added that 'the existence of a contractual relationship is not inconsistent with judicial review'59 In that way, the court replaced a strict 'source of power' approach to such matters with a more functional approach as it has been on the rise since the recognition of 'hybrid public authorities' under the 1998 Human Rights Act. ${ }^{60}$

A principled opponent against any divide between public and private law is Dawn Oliver, who argues that the distinction has become pointless in modern society. On Oliver's view, both public and private law are about controlling power; neither the quality of an actor as a public or a private body nor the public or private nature of its actions should, in her opinion, make any legal difference. In order to advance and protect a common set of fundamental values like 'autonomy', 'dignity' and 'respect', legal rules and procedures commonly labelled as either private or public should instead be viewed as belonging to a legal continuum without any clear-cut divisions. ${ }^{61}$ The 'common values' that Oliver discerns would be threatened by the public-private divide as a legal construction that is fundamentally strange to the English tradition, uprooting its capacity to offer solutions that fit its ever changing environment. ${ }^{62}$

Instead, Oliver argues for a 'power-pluralist approach' that better suits a neoliberal social reality in which the traditional idea of unilateral enforcement of power as a public prerogative seems to have become untenable. In order to advance the realization of their common values, both public and private law would dispose of 'green light and red light functions', either investing legal actors with legal powers ('green lights') or setting limits to those powers ('red lights'). ${ }^{63}$ Evidently, Oliver rightfully warns against possible failures of the public-private dichotomy in capturing the realities of power in a globalized and privatized society. Rather than understanding common law as private law, as Dicey seemed to do, she advances a powerful argument for the

\footnotetext{
$5^{8} \quad$ R. v. Disciplinary Committee of the Jockey Club ex p Aga Khan [1993] I WLR 9og.

$59 \quad R .($ Mullins) v. the Jockey Club [2005] EWHC 2197.

$60 \quad$ Cf., e.g., C. Harlow and R. Rawlings, Law and Administration (Cambridge: Cambridge University Press, 2009) p. 380.

61 Oliver (supra note 48) p. 60.

$62 \quad$ Ibid.pp. 64-65.

$63 \quad$ Ibid. pp. $1-4$.
} 
transplantation of the public law mind-set in other areas of law, protecting citizens against undue exercise of power more generally. ${ }^{64}$

In a sociological sense, it may be true that the state is an organisation that does not essentially differ from any other organisation, whatever its rhetoric of public goods and common interests tells us. ${ }^{65}$ That does not mean, however, that the public interest has completely lost its validity as a normative concept, binding state actors as a point of central reference. In fact, one needs the notion of the public interest to be able to criticize the usurpation of the public sphere by private interests. ${ }^{66}$ Vice versa, the private sphere and private values need a public sphere 'in order to be identified, defined, and, most importantly, protected'.67 Of course, the regulatory state has seen the rise of many hybrid phenomena that are hard to categorize along the public-private axis. That does not mean, however, that the public-private distinction is now bereft of its value as a conceptual differentiation altogether. ${ }^{68}$ Modern difficulties in establishing a persuasive descriptive theory of public and private law need not necessarily imply that one should get rid of the distinction altogether, dismissing any of its prescriptive value just because the distinction between public and private law is often hard to make. ${ }^{69}$

Certainly, it may be fair to subject private actors to legal responsibilities that go beyond the mere obligation not to infringe the subjective rights of others; that does not mean, however, that they should be totally bereft of their fundamental private autonomy, pursuing their own happiness and advancing their own interests in ways that seems most fit to each. ${ }^{70}$ At the same time, it

$64 \quad$ Ibid.pp. 248-249.

65 As it was already propounded by G. Simmel, Soziologie. Untersuchungen über die Formen der Vergesellschaftlichung (Berlin: Duncker \& Humblot, 1908) p. 3.

66 N. Verheij, "From Public Law to Private Law. Recent Developments in the Netherlands", $L a$ Revue administrative 53 (2) (2000) 59.

67 C. Mac Amhlaigh, "Defending the Domain of Public Law", in: C. Mac Amhlaigh, C. Michelon and N. Walker (eds), After Public Law (Oxford: Oxford University Press, 2013) pp. 124-128. For the interdependence or 'co-originality' of public and private values, see also J. Habermas, "Constitutional Democracy: A Paradoxical Union of Contradictory Principles?", Political Theory 766 (2001) $766-767$.

68 Cf. Bogdandy (supra note 4) 13, explaining that the public-private distinction does not deny the existence of hybrid legal phenomena. On Bogdandy's view, such phenomena 'do not undermine but rather reinforce the distinction: any observation of hybridity requires an understanding of the individual components that render something hybrid; a hybrid car is a car that uses a combus-tion engine and an electric motor, and a mule is a cross between a horse and a donkey'.

69 See also Cane (supra note 53) pp. 11-18.

$70 \quad$ Cf., e.g., T. Cornford, Towards a Public Law of Tort (London: Routledge, 2016) p. 88. 
may be useful to remind public actors that they have no legitimate interests of their own, strictly bound as they are to the pursuit of public purposes. The more so, perhaps, at the backdrop of a transformed public space that is filled with public and private actors that both seem primarily intent on their own survival rather than on anything else. ${ }^{71}$ The idea of public law refers to relations of subordination that are not justified by direct consent - different from what is archetypically the case under private law. The 'publicness' of public law thus requires a distinct operational logics and distinct standards of justification. The incremental development of English law - stuck in an ideology of a 'stateless society' at first, but now rapidly recognizing the need for a theory that acknowledges the distinctness of public law as a legal domain that is governed by its own procedures and principles - seems to acknowledge this.

\section{4 Public Law as Exception}

Like French law, Dutch administrative law has strong intellectual roots in the idea of the state as an artificial construct that liberates its citizens from the harsh forces of nature, with strict legal verticality and the primacy of the general interest being indispensable to liberate citizens from interpersonal dependencies like they existed in the feudal era. ${ }^{72}$ Initially, Dutch doctrinal thought was strongly opposed to the idea review of government actions by the ordinary courts altogether, adhering to the French maxim that 'juger l'administration, c'est encore administrer'. Moreover, it followed the French example of understanding the trias politica as a strict separation of powers, with strong restrictions preventing the court to 'occupy the seats' of the administration and the legislature.

Unlike French law, however, Dutch law failed to develop a coherent system of protection against government actions that could serve as a viable alternative. With the state leaving its insular position and deeply penetrating into society, the civil courts felt obliged to fill the gap. They did so by embracing the 'general law doctrine', understanding private law as 'organic' and 'bottom-up' law, only infringed by public law as a domain of artificial exception. Like English common law, this doctrine awarded the courts with a general jurisdiction in government matters; unlike English law, however, it reserved an 'artificial'

\footnotetext{
71 Cf., e.g., N. Luhmann, Gesellschaft der Gesellschaft (Frankfurt am Main: Suhrkamp 1998) p. $16 \mathrm{ff}$. See also van den Berge (supra note 15) pp. 227-228.

72 See, e.g., L. van den Berge, Bestuursrecht tussen autonomie en verhouding (The Hague: Boom juridisch, 2016) p. 81ff, with further references.
} 
domain of public law in which the government remained exempt from 'organic' legal principles, only bound by an underdeveloped set of public law rules. ${ }^{73}$ Only recently, the general law doctrine has been replaced by a more mature alternative, breaking with the idea of administrative law as something artificial. The idea of 'public law as exception', however, is still deeply ingrained in Dutch doctrinal thought, bestowing administrative law with a rather formalist and abstract identity that has proved to be extremely pervasive in Dutch legal culture. ${ }^{74}$

The idea of administrative law as an artificial domain exempt from common law can be traced back to the formalist theories of public law of J.T. Buys (1826-1893) and J.A. Loeff (1858-1921) as two of its most prominent 'founding fathers'. With characteristic fin-de-siècle pathos, Buys described the public order as a man-made artifice, a 'bulwark of freedom', providing the only defence against the natural right of the stronger as the ultimate driving force of uncontrolled society. Enforcing the 'collective will' of its citizens, the state would be engaged in a precarious dialectical relation with society as a realm of clashing private interests. To be sure, Buys recognizes the need for a civil society as a sphere of private autonomy. In lack of regulation, however, society may 'rear suppression', leaving individual citizens helpless against the 'might makes right' of nature. The state, then, is described as the 'banner of freedom' under which the right of the stronger may yield to the law as the people's 'general will'. Only an artificial set of public law rules, establishing strict legal verticality and purely concentrating on the abstract general interest may prevent the bulwark from falling. ${ }^{75}$

In similar vein, Loeff adhered to an imperativist notion of law in which the state is recognised as an 'absolute master' ruling its subjects in the unbound artificial sovereignty that would, paradoxically, be indispensable for the fulfilment of its liberating task, redeeming its subjects from the intersubjective dependencies in which they would be entangled in the state of nature. In Loeff's view, a theoretical basis for administrative law should not be sought in the 'mistaken notion' of 'public subjective rights' on the part of citizens,

73 See esp. J. van der Hoeven, De drie dimensies van bestuursrecht (Alphen aan den Rijn: Samsom H.D. Tjeenk Willink, 1989) p. 145 ff.

74 F.J. van Ommeren, "Governance and the Public-Private Law Divide in the Netherlands", in: A. Colombi Ciacchi and others (eds.), Law \& Governance. Beyond the Public-Private Law Divide? (The Hague: Eleven, 2013) pp. 1-23.

75 See L. van den Berge, "Het schelpdier en zijn schelp. Johannes Theodoor Buys (1826-1893) over administratieve rechtspraak", in: D. de Ruysscher and others (eds.), Rechtsgeschiedenis op nieuwe wegen. Legal history, moving in new directions (Antwerpen: Maklu, 2015) pp. 133-168 for a more detailed account of Buys' legal thought and further references. 
incompatible as they would be with a 'civil state' in which the state is artificially invested with absolute sovereignty. In Loeff's positivist legal universe, there are no unwritten principles or rules from common law that bind the state towards its citizens; instead, a stable legal order would only be possible with the state being exempt from these principles. ${ }^{76}$

With the rise of the welfare state, however, the notion of the state as an absolute master - paradoxically liberating its subjects by establishing a civilized order that recognizes the principle of equal freedom - lost much of its rhetorical force. An influential scholar like Hugo Krabbe (1857-1936), for example, remarked that the establishment and protection of such an order comprises 'perhaps only one percent of the state's functions', with the remainder being usurped by more profane tasks like 'the conveyance of letters and parcels' and 'the management of railways.' ${ }^{77}$ Therefore, Krabbe argued for 'the sovereignty of the law' to replace the idea of the sovereignty of the state, with the state no longer elevated high above the law, but falling under the law instead, bound by legal duties and obligations not essentially different from those that bind its citizens.

A similar theory was laid out by H.J. Hamaker (1844-1911), observing that the deep penetration of the state into society is irreconcilable with the idea of the state as a legal actor exempt from law. Like Krabbe, Hamaker argued that the state can no longer be viewed as some artificial giant towering high above its subjects, only bound to its own statutory commands; instead, the state would also be subjected to unwritten rules and principles that precede these commands, entangled with its citizens in horizontal legal relations governed by private law as 'general law' ${ }^{78}$ However, Krabbe and Hamaker refrain from discarding the public-private divide altogether. Subscribing to the importance of a mighty state that is capable of performing its liberating task, releasing us from interpersonal dependencies, their theories both acknowledge public law as a legal domain of exception in which the abstract notions of strict legal verticality and the undivided general interest - with the state ruling its subjects as a sovereign master - remains untouched. By default, the government

76 J.A. Loeff, Publiekrecht tegenover privaatrecht (Leiden: Ijdo, 1887); J.A. Loeff, "Wenschelijkheid van administratieve rechtspraak hier te lande", Themis 31(1) (1912) 144-172. See also L. van den Berge, “'Der Staat soll Rechtsstaat Seyn'. Loeff, Struycken en de Duitse staatsfilosofie", RM Themis 175(2) (2014) 80-88, with further references.

77 H. Krabbe, Die Lehre der Rechtssouveränität. Beiträge zur Staatslehre (The Hague: Martinus Nijhoff, 1906) p. 35 .

78 H.J. Hamaker, “De tegenstelling van publiek- en privaatrecht”, in: H.J. Hamaker, Verspreide geschriften (Haarlem: Bohn, 1913) pp. 148-153. 
is bound by law like any other legal subject, except within a discretionary domain - clearly fenced off from private law by the legislature - in which the state's absolute public imperium remains unbroken. ${ }^{79}$

With proposals for judicial review by administrative courts being held off by parliament, the civil courts embraced the 'general law doctrine' as it was developed by Hamaker and Krabbe in order to provide for legal protection against government actions on their own accord. In ground-breaking cases like Guldemond v Noordwijkerhout (1915) and Ostermann (1924), the Dutch Supreme Court declared the ordinary courts competent in any case in which the applicant asks to be protected against the infringement of a 'civil right', without regard to the public or private nature of the legal relation to the purported wrongdoer. ${ }^{80}$ Respecting public law as a realm of artificial exception, however, the civil courts - though generally competent - hold themselves inaccessible for claims against government actions that the legislature has explicitly exempted from their jurisdiction.

In this way, a public-private distinction came to be drawn between 'administrative acts' (Verwaltungsakte) on the one hand and other acts of government on the other. ${ }^{81}$ One-sided decisions about the legal positions of individual citizens - taken by the government while performing its task of lawfully distributing rights and goods - thus remained outside of the scope of judicial review as it was offered by the ordinary courts. Within the 'exceptional domain' of its administrative decisions, the idea was long upheld that the administration should reign supreme, with only the government itself having the final say on their validity. Only in the wake of the Benthem v Netherlands (1985), judicial review of administrative acts was entrusted to fully independent administrative courts by the General Administrative Law Act (GALA) of $1994 .{ }^{82}$ The guise

79 See esp. Van der Hoeven (supra note 66) p. 145ff.

80 Guldemond v Noordwijkerhout, HR 31 December 1915 [1916] NJ 416; Ostermann I, HR 20 November 1924 [1925] NJ 89. See also G. Jurgens and F.J. van Ommeren, "The PublicPrivate Divide in English and Dutch Law: a Multifunctional and Context-Dependant Divide", Cambridge Law Journal 71(1) 182.

81 See also R. Seerden and F. Stroink, "Administrative Law in the Netherlands", in: R. Seerden (ed), Administrative Law of the European Union, its Member States and the United States. A Comparative Analysis (Antwerpen: Intersentia, 2007) p. 184ff; O. Jansen, "A Few Characteristics of Administrative Procedure in the Netherlands", in:J.B. Auby (ed), Comparative Law of Administrative Procedure (Bruxelles: Bruylant, 2016) pp. 101-119, with 104-107 explaining the dogmatics of the administrative act.

82 Benthem $v$ Netherlands (1985) 8 EHHR 1; see on the historical development of an independent administrative court system esp. M Schreuder-Vlasblom, De macht der kritiek (Groningen: s.n., 1987). 
of the administrative act as the alpha and omega of the administrative court's jurisdiction, however, has survived up to the present day, burdening administrative law with a vertical and rather abstract legal grammar that seems out of touch with the horizontalized and privatized social reality that it is supposed to regulate. ${ }^{83}$

As it is widely agreed upon, the traditional Dutch idea of the government being above the law, operating within some extra-legal domain in which it is only under democratic control, is now outdated. With the shift from government to governance entrusting public tasks to a plethora of private and semi-independent public actors, investing them with a host of far-reaching legal powers, the concept of reliable democratic control has lost much of its rhetorical force. Nor does the French conception of public law entailing a special legal regime offer a persuasive solution. With the pervasive 'osmosis' between public and private law that is typical of the neoliberal era, the idea of public law as something completely different from private law seems obsolete, notwithstanding the tenacious persistence of that idea in French legal dogmatics. What, then, could be a way forward for public law, carrying the weight of various traditions and ideological conceptions of the past that now seem out of place? Recent developments in Dutch doctrinal thought may indicate a viable way forward.

In response to the ongoing privatization and horizontalization of the public realm, Dutch legal doctrine has created 'open connections' between public and private law, with written and unwritten principles originally developed in private law now being applied to public law and vice versa. The development of these 'open connections' was driven by a shift of concepts that replaced the formalist understanding of pubic law as a domain of artificial exception with the idea that both public and private law derive from a set of common principles that precede formal rules, providing both legal domains with a shared legal fundament. ${ }^{84}$ For a leading set of legal scholars, however, these common principles do not mean that the public-private divide should be dismissed

83 The use of the administrative act as central criterion demarcating the competence of the administrative court is often criticised. See, e.g., F. van Ommeren and P. Huisman, "Van besluit naar rechtsbetrekking: een groeimodel”, in: Het besluit voorbij (The Hague: Boom Juridische uitgevers, 2013) p. $7 \mathrm{ff}$.

84 See Van Ommeren (supra note 67) for a more detailed account of these developments and further references. 
altogether. United under the banner of the 'common law doctrine' - not to be confused with its English namesake - they trace public and private law back to common legal principles, while at the same time maintaining that the specific nature of each domain requires that the application of these principles works out in separate ways..$^{85}$

To an important extent, the breakdown of the traditional Dutch idea of public law as a domain of artificial exception was driven by the rapid development of the 'general principles of proper government' from the fifties onwards. As the legislative history of the GALA has it, these principles 'reflect a conception of the relation between government and citizen' that differs from the way in which their positions towards each other was perceived in earlier times. The rise of the welfare state would require a more horizontal approach to public law that recognizes public and private parties as actors on a common stage', both actively giving shape to the public domain in mutual interaction. ${ }^{86}$ Denouncing public law's tradition of artificial verticality, the GALA's legislative history strongly opposes the formalist conception of public law as a domain in which the government is exempt from unwritten legal principles. In its dismissal of the positivist conception of public law as some 'legal vacuum', only filled with the legislature's explicit commands, the GALA controversially also accepted the idea of unwritten 'principles of good citizenship' as a natural corollary to the principles binding the government. ${ }^{87}$ To be sure, the GALA does not require private actors to advance the general interest as a primary purpose; that remains the responsibility of the government. Nevertheless, the GALA is built on the idea that public and private actor are both required to take proper heed of each other's position, respecting legitimate interests and expectations in the case at hand.

Whereas the breakdown of public law as a domain of artificial exception was received with general acclaim, the idea of unwritten obligations on the part of private actors met with fierce resistance. Opponents rejected it as an inadmissible 'privatization' or even 'feudalization' of public law, jeopardizing the hard-fought public autonomy of citizens. ${ }^{88}$ Drifting away from its classical focus on abstract legality and the undivided general interest, 'relational

85 See esp. M.W. Scheltema and M. Scheltema, Gemeenschappelijk recht. Wisselwerking tussen publiek- en privaatrecht (Deventer: Kluwer, 2013).

86 Kamerstukken II 1988/89, 21221, 3, 12.

87 R. Foqué, De ruimte van het recht (Arnhem: Gouda Quint, 1992) p. 31.

88 P. de Haan, Recente ontwikkelingen in de verhouding publiek-/privaatrecht (Amsterdam: KNAW, 1999) pp. 22-23; R. Schlössels and S. Zijlstra, Bestuursrecht in de sociale rechtsstaat (Deventer: Kluwer 2010) pp. 48-50. 
administrative law' as it is advanced in the GALA's legislative history would leave citizens unprotected against the government as a 'horizontal partner' who may at any time unveil his true vertical identity, one-sidedly taking legally binding decisions after all. As a distant echo from feudal times, the idea of unwritten legal obligations on the part of private actors would infect public law with the spirit of 'do ut des', ignoring its classical mission of liberating citizens from interpersonal dependencies. Evoking the suggestion of 'cooperation' and 'partnership' between government and citizens, it would ignore the fact that relations in public law are actually overshadowed by a fundamental legal inequality that makes true cooperation and partnership impossible. On such grounds, a leading report on the state of Dutch administrative law has recently dismissed relational administrative law as a paradigm that would be 'irreconcilable with the fundamental principles of Dutch public law'.89

How may such fundamental principles of abstract legality and the undivided general interest be reconciled with the structural transformation of the public sphere as it has taken shape in the modern regulatory state? With the shift from centralized government to network governance having horizontalized and fragmented the public realm, these principles seem more at odds with social and institutional reality than ever before. The new 'common law doctrine' may provide a way out. It understands itself as common because it provides public and private law with a common fundament in unwritten legal principles. Nevertheless, it also acknowledges the unique position of the government among other legal actors as the sole wielder of legitimate force, inhabiting an elevated position that is not only based on substantive disparity, but also on an inequality that is clearly formalized in law. Tracing public and private law back to common principles that conceptually precede the publicprivate law divide, it also awards both legal domains with a distinctive nature that legitimizes differences in the ways that these principles work out within concrete relations..$^{90}$

What, then, should be the conclusion to all this? Modern European systems of public law seem to have no other choice but to respond to their modern context. With the state deeply penetrating into society and the unity of public

\footnotetext{
89 J. de Poorter and K.J. de Graaf, Doel en functie van bestuusrechtspraak: een blik op de toekomst (Den Haag: Sdu, 2011) pp. 99-100.

$90 \quad$ See also Verheij (supra note 62) 57; Van Ommeren (supra note 67).
} 
imperium having broken to pieces, the dividing line between the public and the private has been blurred almost beyond recognition. Being strongly at odds with socio-cultural and economic reality, the ideological imagery of the state as an actor above and detached from society has lost its rhetorical force. Even in France, where the idea of public and private law is deeply ingrained in legal culture, the days of the public and the private as disconnected realms seem numbered. Bruised and battered, the idea of public and private law as 'two separate worlds' more or less survived the 'osmosis' of state and society that is typical of the welfare state. Against the backdrop of the regulatory state, however, it seems on the verge of collapse, with the gap between social and institutional reality on the one hand and ideology on the other now being stretched beyond its maximal expansion.

However, the factual blurring of the dividing line between the public and the private does not necessarily imply that it is now completely bereft of its normative sense. For one thing, private autonomy is only possible when safeguarded by a public order that releases private subjects from interpersonal dependencies, protecting a private sphere of freedom and equality. Moreover, the idea of public law as a legal domain that orients itself on the undivided public interest is of lasting importance - maybe even more so in a neoliberal era in which public authority lies scattered in the hands of a plethora of public and private actors and organizations that merely seem to serve their own institutional interests. The development of English law may serve as an indication of problems that may arise when the idea of public law as a separate legal regime is completely dismissed. The holistic concept of Dicean common law, relying on self-government within a stateless society, has turned out to be an untenable ideology of its own, no longer fit to be applied to a society in which the government aims to steer practically everything.

A theoretical framework recently adopted in Dutch law may indicate a viable way forward. On the one hand, Dutch law now finally seems to have fully acknowledged that public law is not just something artificial, setting aside the rules and principles of private law within a legal domain of exception in which the state reigns supreme. Instead, it has replaced that formalist tradition with a relational theory that presupposes that public law - not different from private law - is most essentially governed by principles that precede the commands of the state, binding both citizens and government by prepositive standards of law from which they cannot be artificially exempted. The leading Dutch doctrine now traces both public and private law back to a set of unwritten ideals and principles as law's common core. At the same time, however, it acknowledges the unique position of the government in one-sidedly determining the legal positions of its subjects, dividing rights and goods among its citizens. 